\title{
The Spillovers of Employment Guarantee Programs on Child Labor and Education
}

\section{Tianshu Li and Sheetal Sekhri}

\begin{abstract}
Many developing countries use employment guarantee programs to combat poverty. This study examines the consequences of such employment guarantee programs for the human capital accumulation of children. It exploits the phased roll-out of India's flagship Mahatma Gandhi National Rural Employment Guarantee Scheme (MGNREGA) to study the effects on enrollment in schools and child labor. Introduction of MGNREGA results in lower relative school enrollment in treated districts. It also finds that the drop in enrollment is driven by primary school children. Children in higher grades are just as likely to attend school under MGNREGA, but their school performance deteriorates. Using nationally representative employment data, the study finds evidence indicating an increase in child labor highlighting the unintentional perverse effects of the employment guarantee schemes for human capital.
\end{abstract}

JEL classification: O12, O15, I25, J21

Keywords: rural employment, human capital, child labor

\section{Introduction}

Both developed and developing countries use employment guarantee programs as a safety net mechanism to reduce poverty and economic vulnerability. ${ }^{1}$ This paper uses the temporal and spatial variation in the roll-out of the Indian government's 2005 National Rural Employment Guarantee Act (NREGA, now named MGNREGA) to evaluate the impact of the policy on children's educational and employment outcomes. Several studies have shown that MGNREGA increased the demand for labor and increased rural wages (Imbert and Papp 2015; Zimmerman 2012). In light of this, the scheme can have profound effects

Sheetal Sekhri (corresponding author) is an associate professor at the University of Virginia, Charlottesville; her email is ssekhri@virginia.edu. Tianshu Li is an assistant professor at the Institute of Urban Development of Nanjing Audit University; his email address is t14bz@virginia.edu. The authors thank Leora Friedberg, Heidi Schramm, and Kartini Shastry for insightful comments. A supplementary online appendix is available with this article at The World Bank Economic Review website.

1 The earliest experiments with this policy lever date back to the 1817 Poor Employment Act and the 1834 Poor Law Amendment Act in Great Britain (Blaug 1963, 1964), and the New Deal programs of the 1930s in the United States (Bernstein 1968; Kesselman 1978). More recently Bangladesh in 1983, Botswana in 1960, Chile in 1987, India in 1978 and 2001, Kenya in 1992, Pakistan in 1992, and the Philippines in 1990, have implemented variants of employment guarantee schemes. See Mukherjee and Sinha (2013) for details. 
on children's education and employment, as it influences the opportunity cost of schooling. Potentially, the value of children's time both in the labor force and at home can increase.

A number of factors make India's flagship MGNREGA program an ideal setting to study the impact of employment guarantee schemes on schooling and child labor. First, the scale of the program is massive. By its fifth year, the program provided employment opportunities to 53 million households for 2.3 billion man-days, making it the world's largest operating employment guarantee scheme. Second, the program was gradually rolled out in the districts of India based on predetermined characteristics measured 10-15 years prior to the program. This variation provides an excellent opportunity to evaluate the impact of this program.

Using a longitudinal data set of 1.13 million primary and upper-primary schools in India, the study compares within-school enrollment across the districts that received the program early versus late. It finds that, conditional on school characteristics, school enrollment grew more slowly in districts where the program was phased in early. This result is driven by primary schools rather than upper-primary schools. Using nationally representative survey data, the study examines the effect on children's employment both outside and within the house. It finds that children are more likely to be employed in early phase districts post treatment. ${ }^{2}$

Responses to the program are heterogeneous. Responses to the program vary by age, type of school, and quality of private schools within private schools. Enrollment falls for younger primary school children whereas school outcomes deteriorate for upper-primary children. Grade 7 school outcomes in early treated districts get worse for both government and private schools, but effects are larger for private schools. Within private schools, the effects are driven by low-quality private schools.

The timing of the roll-out was not random and was largely ascertained by three district characteristics: district Scheduled Castes and Scheduled Tribes population in the 1991 Census of India, 1996-97 agricultural wages, and the 1990-93 output per agricultural worker. The study controls for these characteristics in the analysis. The study also includes both school and year fixed effects to control for school-specific time-invariant heterogeneity, and macro trends in enrollment. It also includes state time trends to control for state-specific funding decisions that may affect school enrollment or performance. Additionally, it includes a very comprehensive set of school- and district-level controls in the empirical analysis. Finally, the study controls for school type by year fixed effects to allow for differential enrollment trends in government and private schools.

To further bolster confidence in the identification, the study conducts a series of robustness tests. First, using the data for three years before the policy was implemented (2003-05) for a large subsample of the states, ${ }^{3}$ the study compares the pre-trends in the districts that received the program early to the ones that received it late. No evidence was found of differential pre-trends in enrollment. Second, using this sample, the study demonstrates that controlling for changes in yearly enrollment from 2003 to 2005 and allowing the trend to vary over time in subsequent years does not change the results. Note that the study also shows that results are similar in the full sample and in the subsample for which pretreatment data are available to rule out bias emerging from selection into the sample. Finally, it was demonstrated that the timing of the change in enrollment coincides with the introduction of MGNREGA in early districts.

The paper contributes to two strands of literature. The first strand examines the causal effects of employment guarantee schemes and other safety net programs on development outcomes. Several other

2 In many settings, children who work a significant number of days in a year are less likely to be enrolled in school (Jensen 2000). The results show that safety net schemes can result in an increase in this phenomenon.

3 Only 10 states and union territories covering a very small fraction of rural India are excluded in the pre-trend comparison. 
studies have evaluated safety net programs, and in particular, this program. ${ }^{4}$ Previous evaluations have shown that MGNREGA increased unskilled wages (Imbert and Papp 2015; Azam 2012; Berg et al. 2012; Zimmermann 2012), female labor force participation (Azam 2012) and household consumption (Ravi and Engler 2015). This study complements this literature and examines the effects of the program on schooling outcomes. The paper does not refute these clear benefits of the program but rather shows that there is an opportunity cost.

There are two studies that are closely related to this paper. Afridi, Mukhopadhyay, and Sahoo (2012) find that MNREGA increases mothers' income and through this channel improves children's educational outcomes. Unlike Afridi, Mukhopadhyay, and Sahoo (2012), an improvement in schooling outcomes was not found. There are a number of differences between the present paper and their study. First, Afridi, Mukhopadhyay, and Sahoo (2012) focus on one state, whereas this paper uses data from the entire country from 2005 to 2008 . Hence, the design makes it possible to understand nationwide effects of the program. Second, they use data from 2007 to 2009. By 2007, MGNREGA was already implemented in the poorest parts of the country, and was being implemented in the rest of the districts. Hence, their study only makes postintroduction comparisons and uses the intensity of exposure for identification. In contrast, the strength of this study design is that it uses the roll-out timing for identification and compares outcomes pre- and postimplementation. This paper also examines a very rich set of schooling outcomes, whereas they focus on time spent in school. Importantly, this study shows that the program has an unintended effect on child labor, increasing likelihood of being employed. In a subsequent study, Shah and Steinberg (2015) use test score data and evaluate the impact of MGNREGA on human capital. Their paper reinforces the findings of the present study. However, there are important dissimilarities. Their study uses the Annual Status of Education Report (ASER) data on test scores ${ }^{5}$ and finds that test scores worsen for children in early roll-out districts. They focus on gender-based age-specific differences in labor outcomes. The present study, on the other hand, uses school-level data and highlights the heterogeneity in outcomes by school type, quality of private schools, and age. There are two major differences that underscore the contributions of the present paper. First, a novel result in the paper shows that the enrollment falls in private schools, which are expensive, rather than in public schools and there is heterogeneity even within private schools. Low-quality schools drive the fall in enrollment in private schools. Second, from an identification perspective, a clear advantage of this paper is that it has three years of pretreatment data for a large subset of these schools. Thus, the confidence in the findings can be strenghtened by demonstrating that there are no differential pre-trends. However, their study design is limited by only one year of pretreatment data in the ASER sample. ${ }^{6}$

Finally, this paper also complements the literature on child labor. ${ }^{7}$ Basu and Van (1998) provide a theoretical model that examines conditions under which children work in the labor market. Edmonds (2005) uses data from Vietnam to examine whether improving standards of living reduces child labor. Edmonds and Pavnick (2005) examine the effect of international trade on children's outcomes. Jacoby and Skoufias (1997) study the effects of financial market incompleteness on human capital accumulation and document that seasonal fluctuation in school attendance is a form of self-insurance by households.

4 See Skoufias and Parker (2003) for an in-depth analysis of the effects of Mexico's PROGRESA (Programa de Educacion, Salud, y Alimentacion) on child outcomes and Skoufias et al. (2001) for effects of PROGRESA on child labor and schooling outcomes. PROGRESA is a conditional cash transfer program where transfers to the households were conditioned on children attending school. So the incentives households face are very different from MGNREGA. Berhane et al. (2014) study the effects of safety net schemes on food security and economic vulnerability.

5 These data are collated by an NGO Pratham and are publicly available.

6 Both these studies use the National Sample Survey Office (NSSO) employment and unemployment survey data to substantiate that the program indeed results in higher labor supply of children.

7 See Basu (1999) for a review of this literature. 
More recently Cascio and Narayan (2015) demonstrate that economic booms resulting from increased fracking in the United States increase high school dropout rates due to an increase in the demand for unskilled labor. The present paper contributes to this literature by examining the effects of employment guarantee schemes on child labor. Program-induced increased labor opportunities for adults induce an increase in child labor.

These findings have important policy implications: without adequate changes in incentives to attend school, large-scale safety net programs designed to smooth household consumption may result in decreased school enrollment and worsening of performance in schools.

The rest of the paper is organized as follows: Section 2 offers more detailed information on the MGNREGA in India. Section 3 presents the data used, and section 4 presents the empirical strategy. Section 5 documents the results. Section 6 offers concluding remarks.

\section{Contextual Information}

\section{Background: National Rural Employment Guarantee Act}

The National Rural Employment Guarantee Act, passed in 2005 (now called the Mahatma Gandhi National Rural Employment Guarantee Act), provides 100 days of guaranteed wage employment per financial year to every individual residing in rural India. The program provides unskilled manual work at the officially determined minimum wage of about 2 USD per day. In any district covered by the program, an adult can apply for work under MGNREGA and is entitled to public works employment works within 15 days; otherwise, the state government provides an unemployment allowance (Ministry of Rural Development 2008b). ${ }^{8}$ This program has been widely claimed to have increased rural wages despite significant leakages from the program. Imbert and Papp (2015) claim that, despite its shortcomings, the program is effective at attracting casual labor relative to the private sector.

The budget for the program is almost 4 billion USD, 2.3 percent of total central government spending, which makes the program the best-funded antipoverty program in India (Ministry of Rural Development 2008a; Azam 2012). The program provided 2.27 billions person-days of employment to 53 millions households in 2010-11 with the whole budget in the country Rs. 345 billions (7.64 billions USD); representing 0.6 percent of the GDP (Imbert and Papp 2015).

\section{Roll-Out of the MGNREGA Program}

MGNREGA was implemented in three phases. Backwardness status of the districts was used to determine roll-out priority. However, each state was provided representation in Phase I. The Planning Commission of India calculated and ranked the backward status of Indian districts (Planning Commission 2003). The official ranking of backwardness of the districts in each state was based on the Scheduled Castes and Scheduled Tribes population in 1991, agricultural wages in 1996-97, and output per agricultural worker in 1990-93. In Phase I, 200 backward districts implemented the program in February 2006. The program was then introduced in an additional 130 districts in Phase II in April 2007, ${ }^{9}$ and all the remaining 270 districts received the program in the last phase in April 2008. ${ }^{10}$ This variation in the

8 The paper discusses some additional program details in the supplementary online appendix, available with this article at The World Bank Economic Review website.

9 The program commenced in May 2007 for 17 Phase II districts in Uttar Pradesh due to state legislative assembly elections.

10 Due to splitting of districts for which data for the parent and split district were not available in all years, the number of districts in the sample are 193,123 , and 254 , respectively. 
timing of the program roll-out makes it possbile to identify the causal effect of this scheme on schooling outcomes. ${ }^{11}$

\section{Data}

The principal source of data is the annual panel of Indian schools called the District Information System for Education (DISE). ${ }^{12}$ The data cover grades 1 through 8 in 1.13 million schools. School characteristics include staff characteristics such as gender and qualification of teachers, infrastructure measures including availability of common toilets, gender-specific toilets, drinking water facilities, electrification, and enrollment by gender and grade. The data also include appearance and pass rates for school examinations for grades 5 and 7, and grade repetition for all grades. Primary schools in India may have only primary classes (grades 1 through 5), only upper-primary classes (grade 6 through 8), or both (grade 1 through 8). The data provide information about whether the school offers only primary classes, only upper-primary classes, or both. The school management categories in the data include (1) Department of Education, (2) Tribal/Social Welfare Department, (3) Local body, (4) Private Aided, (5) Private Unaided, (6) Others, and (7) Un-recognized. The study constructs three aggregate categories: governmentrun schools ( 1 and 2$)$, private schools (4 and 5), and others (3, 6, and 7). In addition to these features, the data report ongoing incentive schemes in various schools to increase enrollment. Various schemes running in schools before MGNREGA provide free uniforms, textbooks, stationery, and attendance fellowships. One concern with the DISE data is that since schools self-report the data, there is measurement error in the data. ${ }^{13}$ The implications of measurement error in the data for the results are addressed in subsequent sections.

The district-level characteristics are from the Census of India 1991 and 2001. These include total population, population growth rate, percentage of female population, literacy rate, female literacy rate, percentage of Scheduled Castes and Scheduled Tribes population, and percentage of working population. Agricultural wages for 1996-97 and total output per agricultural worker for 1990-93 come from the Planning Commission's 2003 report.

Table 1 provides the summary statistics of outcome variables by phases of MGNREGA districts. Consistent with the roll-out criterion, the better-off Phase III districts have better educational outcomes. Conditional on being enrolled, 92 percent of the children pass exams in grade 5 in Phase III districts, whereas 88 percent do in Phase I districts. In Phase III districts, 49 percent of students enrolled score more than 60 percent marks in grade 5 examinations, whereas in Phase I districts only 38 percent do. Similarly, these percentages for grade 7 examinations are 43 percent in Phase III districts and 36 percent in Phase I districts. Additional summary statistics about the schools and districts in different phases are presented in supplementary online appendix S2 in tables S2.1 and S2.2.

11 Prior to February 2006, the government experimented with a pilot program (the Food for Work Program) in November 2004 in 150 of the 200 Phase I districts. Field observations (Bhatia and Dreze 2006) and research studies (Imbert and Papp 2015) have found little evidence of increase in public works due to this pilot.

12 DISE is collected every year in a joint collaboration between the Government of India, UNICEF, and the National University of Educational Planning and Administration (NUEPA). The data are publicly available from NEUPA.

13 These data are collected using a district-level administrative structure. School principals fill out a standardized survey about the school. The data are manually checked at various levels for completeness, accuracy, and inconsistencies. States also implement checks. NEUPA has commissioned an external audit of the school data. These audits check 5 percent of the schools chosen randomly from at least 10 percent of the districts from each state. The auditors also visit the schools. These audits have established that the enrollment data reported by the principals are remarkably accurate. 


\begin{tabular}{|c|c|c|c|c|c|c|c|c|c|c|}
\hline & & \multicolumn{3}{|c|}{ Phase I } & \multicolumn{3}{|c|}{ Phase II } & \multicolumn{3}{|c|}{ Phase III } \\
\hline & & Obs & Mean & Std. & Obs & Mean & Std. & Obs & Mean & Std. \\
\hline \multirow[t]{6}{*}{ Enrollment } & Total & $1,427,624$ & 223.76 & 219.23 & 811,704 & 230.64 & 217.60 & $1,343,989$ & 209.82 & 207.79 \\
\hline & Primary & $1,232,837$ & 219.40 & 198.22 & 690,974 & 228.09 & 197.33 & $1,116,974$ & 201.57 & 190.42 \\
\hline & Upper-primary & 390,848 & 113.01 & 117.09 & 231,646 & 113.02 & 70.65 & 490,679 & 102.12 & 103.60 \\
\hline & Government & $1,006,795$ & 233.43 & 224.016 & 576,487 & 242.60 & 221.82 & 783,388 & 194.43 & 181.14 \\
\hline & Private & 133,146 & 293.19 & 281.59 & 94,408 & 266.93 & 262.30 & 243,666 & 291.22 & 284.06 \\
\hline & Others & 287,683 & 158.72 & 144.31 & 140,809 & 159.30 & 145.04 & 316,935 & 185.54 & 182.38 \\
\hline \multirow{2}{*}{$\begin{array}{l}\text { Passing rate conditional } \\
\text { on being enrolled }\end{array}$} & Grade 5 & 996,134 & 0.88 & 0.21 & 556,877 & 0.90 & 0.19 & 928,972 & 0.92 & 0.17 \\
\hline & Grade 7 & 284,491 & 0.86 & 0.23 & 170,904 & 0.87 & 0.21 & 388,192 & 0.88 & 0.20 \\
\hline \multirow{2}{*}{$\begin{array}{l}\text { Passing rate conditional } \\
\text { on appearing in exams }\end{array}$} & Grade 5 & $1,023,758$ & 0.95 & 0.16 & 578,720 & 0.96 & 0.14 & 947,591 & 0.96 & 0.12 \\
\hline & Grade 7 & 290,747 & 0.90 & 0.20 & 176,551 & 0.91 & 0.19 & 397,070 & 0.91 & 0.18 \\
\hline \multirow{2}{*}{$\begin{array}{l}\text { Passing } 60 \text { conditional } \\
\text { on being enrolled }\end{array}$} & Grade 5 & 997,423 & 0.38 & 0.34 & 558,074 & 0.44 & 0.34 & 930,690 & 0.49 & 0.35 \\
\hline & Grade 7 & 285,758 & 0.36 & 0.34 & 171,654 & 0.36 & 0.32 & 389,877 & 0.43 & 0.33 \\
\hline \multirow{2}{*}{$\begin{array}{l}\text { Passing } 60 \text { conditional } \\
\text { on appearing in exams }\end{array}$} & Grade 5 & $1,021,693$ & 0.40 & 0.35 & 578,103 & 0.46 & 0.35 & 946,941 & 0.51 & 0.35 \\
\hline & Grade 7 & 290,652 & 0.37 & 0.35 & 176,552 & 0.37 & 0.33 & 397,220 & 0.44 & 0.33 \\
\hline
\end{tabular}

Source: Authors' analysis based on data from the District Information System for Education (2005-06 to 2008-09).

\section{Empirical Strategy}

The paper uses the timing of roll-out of the MGNREGA program across districts of India for identification. Phase I districts received the program in February 2006, Phase II in April/May 2007, and Phase III in April 2008. The study uses 2005 as the baseline year and includes data from 2005 to 2008 in the analysis. Later data from 2003 are used for the districts in which it is available to provide support to the identifying assumption.

\section{Roll-out and Selection}

The timing of the roll-out of the program was not randomly determined. Thus, a simple comparison of the districts across different phases is not likely to generate causal estimates of the program. In order to circumvent this issue, outcomes are compared within districts that received the program in different phases over time. This allows the study to control for time-invariant differences in unobserved characteristics of districts that received the program in different phases. The study also uses within-school variation for identification by including school fixed effects to purge any time-invariant school-level characteristics that may be correlated with the treatment.

The study further interacts the three variables determining selection into the phase of roll-out with year indicators to control for trends in these variables. In addition, this study includes a rich set of districtspecific controls including 2001 levels of total population, percentage of rural population, population growth rate, overall literacy rate, and female literacy rate interacted with year indicators. The study also controls for a state-specific time trend to control for state-specific time-varying unobserved heterogeneity, such as discretionary state-level education funding. The study allows for a differential trend for government and private schools over time by interacting school type with year indicators.

The identifying assumption is that the outcomes in districts that received the program in different phases are not trending differentially prior to treatment after controlling for trending program criteria. The study tests this assumption on a subsample of states for which pretreatment data are available. The results show that growth in school enrollment in districts that received the program in different phases is similar prior to the program. It is also shown that the within-school results are invariant to including changes in 
enrollment from 2003 to 2005. Data from 2003 to 2005 for 10 small states and union territories were not available. The study verifies that excluding these 10 states in the empirical analysis does not influence the results to rule out selection into the sample.

\section{Estimation Procedure}

The study uses school-level data from 1.13 million schools from 2005 to 2008 to test the hypotheses. The empirical specification is as follows:

$$
Y_{i d s t}=\alpha_{0}+\alpha_{1} \text { MGNREGA }_{d t}+\alpha_{2} X_{i d s t}+\alpha_{3} Z_{d s} * T_{t}+\alpha_{4} \text { State }_{s} * \text { trend }+T_{t}+I_{i d s}+\epsilon_{i d s t}
$$

where $Y_{i d s t}$ is the outcome variable for school $i$ in district $d$ in state $s$ in year $t . M G N R E G A_{d t}$ is an indicator that takes value 1 if district $d$ in state $s$ has started the MGNREGA program in year $t$, and 0 otherwise; $X_{i d s t}$ is a vector of school-level controls including different kinds of incentives received by the students, and the characteristics of the teachers and infrastructure of the school $i$ in district $d$ in state $s$ in year $t$; $Z_{d s}$ is a vector of district-level controls for demographic characteristics, and these are interacted with year indicators to control for trends in these characteristics, starting at specific levels for which values were available; State $_{s}$ is a vector of state indicators, and is interacted with a linear time trend to control for state-specific trends and account for state spending priorities; $T_{t}$ and $I_{i d s}$ are year- and school-fixed effects, respectively, and $\epsilon_{i d s t}$ is the idiosyncratic error term. The study drops the MGNREGA phase indicators due to multi-collinearity in the school fixed effects model. The study clusters errors at the district level to account for arbitrary correlation over time.

In order to examine the school choices by school type, the study interacts the introduction of MGNREGA with the type of school. The empirical model is as follows:

$$
\begin{aligned}
Y_{i d s t}= & \beta_{0}+\beta_{1} \text { MGNREGA }_{d t}+\beta_{2} P_{i d s} * \text { MGNREGA }_{d t}+\beta_{3} G_{i d s} * \text { MGNREGA } \\
& +\beta_{4} X_{i d s t}+\beta_{5} Z_{d s} * T_{t}+\beta_{6} \text { State }_{s} * \text { trend }+\beta_{7} \text { Schooltype }_{i} * T_{t}+T_{t}+I_{i d s}+\epsilon_{i d s t}
\end{aligned}
$$

where $Y_{i d s t}$ is the outcome variable for school $i$ in district $d$ in state $s$ in year $t$. $P_{i d s}$ is an indicator equal to 1 for private schools and 0 otherwise, and $G_{i d s}$ is an indicator that takes value 1 for government schools and 0 otherwise. The omitted category is others. The study includes the interaction of the MGNREGA policy indicator with each of these type indicators to examine whether effects of the program differ by school type. Schooltype $e_{i}$ are indicators for government and private schools, and these are interacted with year indicators to control for differential trends in different types of schools. Note that once the school fixed effects are included, indicators for school type (private and government) are not included, as these are time-invariant properties of schools. As before, the study also drops the phase indicators due to multicollinearity in the school fixed effects model.

The following outcomes are examined: enrollment, pass rate, pass rate conditional on taking the exams, pass rate of those who pass with more than 60 percent marks. ${ }^{14}$ Note that age-specific population data are not available, so it is not possible to normalize the results by this age-specific population. Instead, the study controls for trends in district-specific total population. ${ }^{15}$

There are three concerns that may confound the interpretation of the results. First, it is possible to spuriously attribute to MGNREGA the effects of other government programs aimed at influencing enrollment. The Government of India introduced two programs in the early 2000s to promote direct enrollment in schools. The first program, the Sarva Shiksha Abhiyan (SSA), was intended to provide universal access to elementary education. The second program was the mid-day meal, which provided cooked meals for children in attendance at schools. However, both programs were launched much earlier than the MGNREGA. The second concern might be that the increase in private schools driven by growth in the private 
school market, independent of the program, affects the results. Significant declines become evident in the enrollment in the private schools. Hence, an increase in the number of schools cannot be causing this decline. Further, the estimates are robust to including state-specific trends, and school type by year fixed effects. Therefore, different trajectories of growth across states are not generating the results. In supplementary online appendix S3 fig. S3.1, the study also shows that phasewise trends in expansion of schools, for both private and public schools, were similar. Thus, an independent increase in demand for private schools is unlikely to be driving the results.

Finally, if MGNREGA attracts migrants into districts, then the results could be driven by changes in population. Across-district migration in India is very low (Topolova 2010). Further, if migration were responsible for the changes in enrollment, then similar-sized effects would be expected for primary and upper-primary grades and individual classes within these grades. In tables 2 and 3, the size of the effect is much larger in primary school with no effect discerned in upper-primary schools. It seems implausible that households with children only in specific age groups would migrate into the MGNREGA districts to find work. ${ }^{16}$

\section{Results}

\section{Overall Enrollment}

In order to evaluate the effect of MGNREGA on enrollment, the study estimates equation (1) and present the results in table 2. Column (1) presents the basic difference-in-difference specification with school and

Table 2. The Impact of Introduction of MGNREGA on Enrollment (2005-06 to 2008-09)

\begin{tabular}{|c|c|c|c|c|c|}
\hline & \multicolumn{5}{|c|}{ Dependent variable: total enrollment } \\
\hline & \multicolumn{3}{|c|}{ Overall enrollment } & \multirow{2}{*}{$\begin{array}{c}\text { Primary } \\
\text { (4) }\end{array}$} & \multirow{2}{*}{$\begin{array}{c}\text { Upper-primary } \\
\text { (5) }\end{array}$} \\
\hline & $(1)$ & $(2)$ & (3) & & \\
\hline MGNREGA commenced & $\begin{array}{c}-2.23 * * \\
(1.01)\end{array}$ & $\begin{array}{c}-2.23 * * \\
(1.02)\end{array}$ & $\begin{array}{c}-1.96 * \\
(0.95)\end{array}$ & $\begin{array}{c}-2.23 * * \\
(1.04)\end{array}$ & $\begin{array}{r}-0.42 \\
(0.56)\end{array}$ \\
\hline Year- \& school-fixed effects & Yes & Yes & Yes & Yes & Yes \\
\hline Controls for backwardness ${ }^{a}$ & Yes & Yes & Yes & Yes & Yes \\
\hline Incentives $^{\mathrm{b}}$ & Yes & Yes & Yes & Yes & Yes \\
\hline Teacher characteristics ${ }^{\mathrm{b}}$ & Yes & Yes & Yes & Yes & Yes \\
\hline School infrastructure ${ }^{\mathrm{b}}$ & Yes & Yes & Yes & Yes & Yes \\
\hline District demographics ${ }^{\mathrm{c}}$ & - & Yes & Yes & Yes & Yes \\
\hline State-specific trends & - & - & Yes & Yes & Yes \\
\hline Observations & & $3,583,317$ & & $3,053,180$ & $1,113,283$ \\
\hline Number of schools & & $1,106,957$ & & 941,390 & 378,324 \\
\hline
\end{tabular}

Source: Authors' analysis based on data from the District Information System for Education (2005-06 to 2008-09).

Note: a) To account for the backward district status that influenced selection into the program, the study controls for Scheduled Castes and Scheduled Tribes population from Census of India 1991, agricultural wage in 1996-97, and output per agricultural worker in 1990-93, interacted with year dummies. b) School Incentive programs include textbooks, stationery, uniforms, attendance scholarship, and other incentives; teacher characteristics include the number of male and female teachers; infrastructure includes the number of classrooms, classrooms in good condition, the existence of common toilet, women's toilet, electricity, and water facilities. c) District-level demographic characteristcs include total population, percentage of urban population, population growth rate, overall literacy rate, and women's literacy rate from the Census of India 2001. Robust standard errors clustered at district level are reported in parentheses. $* * p<0.01, * * p<0.05$, $p<0.1$.

16 Also, anecdotal evidence suggests that beneficiaries use the employment guarantee in summer months. One concern might be that schools are already closed for vacation. However, schools in India generally close for only around 40 days, and the timing varies spatially ranging from mid-May to the end of June in the North to mid-June to end-July in the South. Also, Imbert and Papp (2015) show that the program impacts rural wages in a general equilibrium framework. Given that, there is an incentive to substitute for adult labor year round. 
Table 3. Heterogneous Impact of the Introduction of MGNREGA on Enrollment (2005-06 to 2008-09)

\begin{tabular}{|c|c|c|c|c|c|c|}
\hline & \multicolumn{2}{|c|}{ Total enrollment } & \multicolumn{2}{|c|}{ Primary enrollment } & \multicolumn{2}{|c|}{ Upper-primary enrollment } \\
\hline & (1) & $(2)$ & (3) & (4) & (5) & (6) \\
\hline MGNREGA commenced & $\begin{array}{c}-1.96 * \\
(0.95)\end{array}$ & $\begin{array}{r}-1.44 \\
(1.26)\end{array}$ & $\begin{array}{c}-2.23 * \\
(1.04)\end{array}$ & $\begin{array}{r}-1.59 \\
(1.24)\end{array}$ & $\begin{array}{r}-0.42 \\
(0.56)\end{array}$ & $\begin{array}{c}0.15 \\
(0.83)\end{array}$ \\
\hline $\begin{array}{l}\text { MGNREGA commenced } \\
* \text { Government school }\end{array}$ & & $\begin{array}{c}0.39 \\
(1.83)\end{array}$ & & $\begin{array}{c}0.74 \\
(1.90)\end{array}$ & & $\begin{array}{r}-1.07 \\
(1.03)\end{array}$ \\
\hline $\begin{array}{l}\text { MGNREGA commenced } \\
\text { "Private school }\end{array}$ & & $\begin{array}{l}-8.21 * * \\
(3.38)\end{array}$ & & $\begin{array}{c}-12.49 * * * \\
(4.10)\end{array}$ & & $\begin{array}{r}-0.38 \\
(1.46)\end{array}$ \\
\hline Gvt school*year dummies & - & Yes & - & Yes & - & Yes \\
\hline Pvt school*year dummies & - & Yes & - & Yes & - & Yes \\
\hline Year- \& school-fixed effects & Yes & Yes & Yes & Yes & Yes & Yes \\
\hline Controls for backwardness ${ }^{a}$ & Yes & Yes & Yes & Yes & Yes & Yes \\
\hline Incentives ${ }^{b}$ & Yes & Yes & Yes & Yes & Yes & Yes \\
\hline Teacher characteristics ${ }^{b}$ & Yes & Yes & Yes & Yes & Yes & Yes \\
\hline School infrastructure ${ }^{b}$ & Yes & Yes & Yes & Yes & Yes & Yes \\
\hline District demographics ${ }^{c}$ & Yes & Yes & Yes & Yes & Yes & Yes \\
\hline State-specific trends & Yes & Yes & Yes & Yes & Yes & Yes \\
\hline Observations & $3,583,317$ & & $3,053,180$ & & $1,113,283$ & \\
\hline Number of schools & 1106957 & & 941,390 & & 378,324 & \\
\hline
\end{tabular}

Source: Authors' analysis based on data from the District Information System for Education (2005-06 to 2008-09).

Note: a) To account for the backward district status that influenced selection into the program, the study controls for Scheduled Castes and Scheduled Tribes population from Census of India 1991, agricultural wage in 1996-97, and output per agricultural worker in 1990-93, interacted with year dummies. b) School Incentive programs include textbooks, stationery, uniforms, attendance scholarship, and other incentives; teacher characteristics include the number of male and female teachers; infrastructure includes the number of classrooms, classrooms in good condition, the existence of common toilet, women's toilet, electricity, and water facilities. c) District-level demographic characteristcs include total population, percentage of urban population, population growth rate, overall literacy rate, and women's literacy rate from the Census of India 2001. Robust standard errors clustered at district level are reported in parentheses. $* * p<0.01, * * p<0.05$, $p<0.1$.

year fixed effects. This result is robust to controlling for state-specific time trends as reported in column (2). Both specifications control for district-level controls that influenced the roll-out timing. The study controls for the Scheduled Castes and Scheduled Tribes population from the Census of India 1991, agricultural wage in 1996-97, and output per agricultural worker in 1990-93, interacted with time indicators. This accounts for differential trends in districts with the backward district status that influenced selection into the program. In addition, the study controls for trends in districts-level total population, percentage of urban population, population growth rate, overall literacy rate, and women's literacy rate in a similar manner. ${ }^{17}$ The school-level controls include any attendance scholarships being offered at the time, uniform, books, stationery, and other such subsidies offered to girls, the number of classrooms, the number of classrooms in good condition, availability of common toilets, girls' toilets, drinking water facilities, electrification status, number of male teachers, and number of female teachers.

The coefficient in columns (1) and (2) is -2.23 and is statistically significant at the 5 percent level. Overall, enrollment in this period is increasing, and thus this coefficient indicates that introduction of MGNREGA results in a smaller annual increase in school enrollment in treated districts. Hence, implementation of MGNREGA results in relative slower growth in enrollment, with two fewer children enrolled per school in the treated districts.

When split by primary and upper-primary grades, it is clear that this effect is driven by primary classes where the magnitude is 2.23 (columns (4) and (5)). No change in the enrollment of children in upperprimary classes was found. Since these children are already past elementary school (which is free in case

17 It was observed that the effects were no different if these co-variates were not included. 
of government schools), it is possible that households do not want to withdraw these children from schools as they have invested in their schooling substantially. ${ }^{18}$

\section{Effects on Enrollment by Type of Schools}

In order to examine if the type of school that children attend is affected, the study evaluates equation (2) and reports the results in table 3, which shows the interaction of the MGNREGA dummy interacted with school types indicators. The excluded category is "other types" schools. Columns (1), (3), and (5) repeat the results of the estimation of equation (1) for overall enrollment, primary enrollment and upper-primary enrollment with additional controls for school type by year fixed effects.

Overall enrollment in government schools is unaffected, whereas enrollment reduces significantly for private schools (column (2)). The coefficient on the interaction term with the private school indicator is significant at the 5 percent level. This result is driven by primary schools (columns (3) to (6)). ${ }^{19}$ Since 66 percent of the schools in the data are government schools and only 13 percent are private schools, the decrease in enrollment per private school is much larger in magnitude. The effect of the program on overall enrollment is small in magnitude. Using the average number of government, private, and other schools per district in the sample period, the results indicate that 9,824 children per district are not attending school due to the program..$^{20}$

The identifying assumption is that there are no pre-trends in enrollment in districts belonging to different phases prior to MGNREGA's implementation. DISE data are not available for all states prior to 2005, although major states are covered since 2003. The study uses data from 2003 to 2005 to check if there are differential pre-trends in enrollment by phases of MGNREGA roll-out. ${ }^{21}$ In table S3.2 in the supplementary online appendix, the study controls for district-specific changes in enrollment from 2003 to 2005 (pretreatment years) and allows this to vary over time by interacting with year indicators for the states for which preprogram data are available. ${ }^{22}$ The overall effects on enrollment and enrollment by primary and upper-primary are similar to those reported in table 3.

Prior to the program implementation, it can be observed that the Phase III districts are better in levels. But the growth rate in enrollment is similar. Figures S3.2 and S3.3 in the supplementary online appendix show that between 2003 and 2005, the growth in enrollment and number of schools looks similar across

18 However, it is also possible that households that are employed in MGNREGA sites are younger and do not have children beyond the primary grades. The subsequent analysis does observe heterogenous effects on children in upper-primary schools as well. Hence the study did not conclude that participating households' demographic composition is driving these results.s

19 In the previous version of the paper, where it did not include the school type (private, public, or others) by year fixed effects, the decreases in enrollment were being driven by public schools, and private school enrollment actually seem to have improved. However, the authors thank an anonymous referee for suggesting that enrollment in different school types could be trending differentially, and this needs to be accounted for by including the school type times year fixed effects.

20 In results not shown, no differences in effects for girls versus boys were found.

21 The supplementary online appendix discusses the fact that the main results are no different if the study excludes or includes the states for which DISE data prior to 2005 were not available. It is reassuring that the sample for which data prior to 2005 are available is not systematically different. The results are reported in table S3.1. Limited data for a few states are also available for 2001 and 2002, but the coverage is not as expansive. Since data for many states and many variables are not available, these years were not used.

22 The study lost 0.7 percent of the sample schools as new districts were carved in 2004, and their pre-trend data could not be used. The study also checks the consistency of results when excluding those schools without pre-trends in table S3.3 in the supplementary online appendix. 
districts in different phases. These two tests together show that pre-trends in enrollment are not biasing the results. ${ }^{23}$

As discussed earlier, a concern with the DISE data is that there is measurement error in reporting. Since school headmasters provide the information, it could be inaccurate as they may have incentives to inflate enrollment numbers. If the policy change does not change the reporting behavior of the headmasters differently in districts of different phases, the double-differencing approach should yield unbiased estimates. However, if the policy change systematically changes the reporting behavior, then the estimates could be biased. For the results to be generated by measurement error, the schools in the early phases districts would have to under-report enrollment, and this would have to vary across public and private schools and primary and upper-primary schools, which is highly unlikely.

There is also a tremendous amount of heterogeneity in the quality of private schools. Hence, the study examines if the quality of the private schools influences household decisions. Private schools are expensive but may not necessarily be of good quality. If the private schools are split into quartiles of the studentteacher ratio, it can be seen that the drop in enrollment in private schools is driven by poor-quality private schools that have very high student-teacher ratios. The interactions of the highest two quartiles with thresholds of 1.35 teachers to 100 children and 2.3 teachers to 100 children with the NREGA commenced indicator are negative, large, and statistically significant. These results are presented in table 4 and are very important from a policy perspective. These findings indicate that households are responsive to the quality of the schools when making investment decisions about children's human capital. Low-quality private schools could have lower returns to schooling or could be admitting more marginal students. Hence, when the opportunity cost of a child's time in school increases, parents withdraw their children from such low-quality schools. This also highlights that the private schools are not always an optimal schooling choice for the households.

\section{Schooling Outcomes}

Absenteeism from school or devoting fewer hours to school work can influence performance outcomes, even if the child is enrolled in school. Hence, the study also examines effects on schooling outcomes. For grades 5 and 7, the data report whether a student passed the exam and if he or she passed with more than 60 percent marks.

Table 5 shows that the passing rate in government schools falls by 1.8 percent for grade 7 students (columns (2) and (4)) with the coefficient significant at the 10 percent significance level, whereas there is no effect on grade 5 (columns (1) and (3)). The program affects passing with more than 60 percent marks much more significantly. Both private and government school seventh graders do worse on this measure. This effect is almost twice as large for government schools as for private schools, and the difference is statistically significant (columns (6) and (8)). ${ }^{24}$

\section{Mechanisms}

In order to shed light on the mechanism, the study examines the employment outcomes of children in the DID framework. The data on child labor come from the National Sample Survey Organization (NSSO) employment and unemployment surveys (rounds 2004-05 to 2008-09), and the study employs earlier rounds to carry out a falsification check. The data ask individuals to identify their principal

23 Supplementary Online Appendix S3 further substantiates the identification by showing in a year-by-year comparison of early versus late districts, that the decline in enrollment occurs in 2006 after the early phases are treated. Figure S3.4 depicts this in a graph. The study also conducted a placebo test to rule out pre-trends in the results for children's employment to ensure credibility of the findings. The results are discussed in the supplementary online appendix.

24 The program does not affect the students' appearing at exams conditional on enrollment, as reported in table S3.4 in supplementary online appendix S3. 
Table 4. Heterogeneous Impact Within Private Schools by Teacher-to-Student Ratio in 2005-06 (2005-06 to 2008-09)

\begin{tabular}{|c|c|c|c|c|c|c|c|c|c|}
\hline & \multicolumn{3}{|c|}{ Total enrollment } & \multicolumn{3}{|c|}{ Primary enrollment } & \multicolumn{3}{|c|}{ Upper-primary enrollment } \\
\hline & (1) & $(2)$ & (3) & $(4)$ & (5) & (6) & (7) & (8) & (9) \\
\hline MGNREGA commenced & $\begin{array}{l}-9.76^{* * *} \\
(3.40)\end{array}$ & & $\begin{array}{r}-2.462 \\
(3.427)\end{array}$ & $\begin{array}{l}-12.44 * * * \\
(3.91)\end{array}$ & & $\begin{array}{c}0.156 \\
(4.048)\end{array}$ & $\begin{array}{r}-1.60 \\
(1.74)\end{array}$ & & $\begin{array}{r}-2.152 \\
(1.951)\end{array}$ \\
\hline $\begin{array}{l}\text { MGNREGA commenced*lowest } \\
\text { quartile for teacher to student ratio }\end{array}$ & & $\begin{array}{r}-20.54 * * \\
(8.950)\end{array}$ & $\begin{array}{r}-18.07^{*} \\
(9.504)\end{array}$ & & $\begin{array}{c}-26.53 * * * \\
(9.373)\end{array}$ & $\begin{array}{l}-26.69 \% \\
(10.14)\end{array}$ & & $\begin{array}{r}-1.790 \\
(4.062)\end{array}$ & $\begin{array}{c}0.362 \\
(4.145)\end{array}$ \\
\hline $\begin{array}{l}\text { MGNREGA commenced } * 2 \text { nd lowest } \\
\text { quartile for teacher-to-student ratio }\end{array}$ & & $\begin{array}{c}-11.70 * * * \\
(3.957)\end{array}$ & $\begin{array}{c}-9.242 * * \\
(3.974)\end{array}$ & & $\begin{array}{c}-13.84 * * * \\
(3.955)\end{array}$ & $\begin{array}{c}-13.99 * * * \\
(4.470)\end{array}$ & & $\begin{array}{l}-2.103 \\
(2.695)\end{array}$ & $\begin{array}{l}0.0493 \\
(2.728)\end{array}$ \\
\hline $\begin{array}{l}\text { MGNREGA commenced } * 3 \text { rd lowest } \\
\text { quartile for teacher-to-student ratio }\end{array}$ & & $\begin{array}{r}-3.864 \\
(3.906)\end{array}$ & $\begin{array}{c}-1.402 \\
(2.950)\end{array}$ & & $\begin{array}{r}-3.212 \\
(4.241)\end{array}$ & $\begin{array}{r}-3.367 \\
(3.447)\end{array}$ & & $\begin{array}{r}-1.657 \\
(2.002)\end{array}$ & $\begin{array}{c}0.495 \\
(1.769)\end{array}$ \\
\hline $\begin{array}{l}\text { MGNREGA commenced *highest } \\
\text { quartile for teacher-to-student ratio }\end{array}$ & & $\begin{array}{r}-2.462 \\
(3.427)\end{array}$ & & & $\begin{array}{c}0.156 \\
(4.048)\end{array}$ & & & $\begin{array}{r}-2.152 \\
(1.951)\end{array}$ & \\
\hline \multicolumn{10}{|l|}{ Each teacher-to-student ratio quantile } \\
\hline *Year dummies & - & Yes & Yes & - & Yes & Yes & - & Yes & Yes \\
\hline Year- \& school-fixed effects & Yes & Yes & Yes & Yes & Yes & Yes & Yes & Yes & Yes \\
\hline Controls for backwardness ${ }^{\text {a }}$ & Yes & Yes & Yes & Yes & Yes & Yes & Yes & Yes & Yes \\
\hline Incentives, teacher, $\&$ infrastructure ${ }^{b}$ & Yes & Yes & Yes & Yes & Yes & Yes & Yes & Yes & Yes \\
\hline District demographics ${ }^{c}$ & Yes & Yes & Yes & Yes & Yes & Yes & Yes & Yes & Yes \\
\hline State-specific trends & Yes & Yes & Yes & Yes & Yes & Yes & Yes & Yes & Yes \\
\hline Observations & & 358,162 & & & 255,817 & & & 199,512 & \\
\hline Number of schools & & 101,276 & & & 76,131 & & & 61,302 & \\
\hline
\end{tabular}

Source: Authors' analysis based on data from the District Information System for Education (2005-06 to 2008-09).

Note: a) To account for the backward district status that influenced selection into the program, the study controls for Scheduled Castes and Scheduled Tribes population from Census of India 1991, agricultural wage in 1996-97, and output per agricultural worker in 1990-93, interacted with year dummies. b) School incentive programs include textbooks, stationery, uniforms, attendance scholarship, and other incentives; teacher characteristics include the number of male and female teachers; infrastructure includes the number of classrooms, classrooms in good condition, the existence of common toilet, women's toilet, electricity, and water facilities. c) District-level demographic characteristcs include total population, percentage of urban population, population growth rate, overall literacy rate, and women's literacy rate from the Census of India 2001. Robust standard errors clustered at district level are reported in parantheses. ***p<0.01,**p $<0.05, * p<0.1$.

Table 5. The Impact of the Introduction of MGNREGA on Performance Outcomes (2005-06 to 2008-09, Unit: \%)

\begin{tabular}{|c|c|c|c|c|c|c|c|c|}
\hline & \multicolumn{2}{|c|}{ Pass/enrollment } & \multicolumn{2}{|c|}{ Pass/appearing at exam } & \multicolumn{2}{|c|}{ Pass 60/enrollment } & \multicolumn{2}{|c|}{$\begin{array}{c}\text { Pass 60/appearing in } \\
\text { exam }\end{array}$} \\
\hline & $\begin{array}{l}\text { Grade } 5 \\
\quad(1)\end{array}$ & $\begin{array}{l}\text { Grade } 7 \\
(2)\end{array}$ & $\begin{array}{l}\text { Grade } 5 \\
\text { (3) }\end{array}$ & $\begin{array}{c}\text { Grade } 7 \\
(4)\end{array}$ & $\begin{array}{l}\text { Grade } 5 \\
(5)\end{array}$ & $\begin{array}{l}\text { Grade } 7 \\
(6)\end{array}$ & $\begin{array}{l}\text { Grade } 5 \\
(7)\end{array}$ & $\begin{array}{l}\text { Grade } 7 \\
\quad(8)\end{array}$ \\
\hline MGNREGA commenced & $\begin{array}{c}0.39 \\
(0.42)\end{array}$ & $\begin{array}{r}-0.34 \\
(0.63)\end{array}$ & $\begin{array}{c}0.34 \\
(0.34)\end{array}$ & $\begin{array}{r}-0.06 \\
(0.62)\end{array}$ & $\begin{array}{c}0.42 \\
(0.73)\end{array}$ & $\begin{array}{l}3.52 * * \\
(1.73)\end{array}$ & $\begin{array}{c}0.36 \\
(0.74)\end{array}$ & $\begin{array}{l}3.75 * * \\
(1.78)\end{array}$ \\
\hline $\begin{array}{l}\text { MGNREGA commenced } \\
\text { *Govenment school }\end{array}$ & $\begin{array}{r}-0.47 \\
(0.67)\end{array}$ & $\begin{array}{c}-1.84 * \\
(1.01)\end{array}$ & $\begin{array}{r}-0.43 \\
(0.58)\end{array}$ & $\begin{array}{c}-1.71 * \\
(0.98)\end{array}$ & $\begin{array}{r}-0.25 \\
(0.88)\end{array}$ & $\begin{array}{l}-5.98^{* * *} \\
(1.83)\end{array}$ & $\begin{array}{r}-0.28 \\
(0.89)\end{array}$ & $\begin{array}{l}-6.11 * * * \\
(1.89)\end{array}$ \\
\hline $\begin{array}{l}\text { MGNREGA commenced } \\
\text { "Private school }\end{array}$ & $\begin{array}{r}-0.35 \\
(0.53)\end{array}$ & $\begin{array}{r}-0.54 \\
(0.65)\end{array}$ & $\begin{array}{r}-0.25 \\
(0.37)\end{array}$ & $\begin{array}{r}-0.43 \\
(0.56)\end{array}$ & $\begin{array}{c}0.85 \\
(0.87)\end{array}$ & $\begin{array}{l}-3.80 * * \\
(1.70)\end{array}$ & $\begin{array}{c}0.85 \\
(0.87)\end{array}$ & $\begin{array}{c}-4.02 * * \\
(1.74)\end{array}$ \\
\hline Gvt school*year dummies & Yes & Yes & Yes & Yes & Yes & Yes & Yes & Yes \\
\hline Pvt school*year dummies & Yes & Yes & Yes & Yes & Yes & Yes & Yes & Yes \\
\hline Year- \& school-fixed effects & Yes & Yes & Yes & Yes & Yes & Yes & Yes & Yes \\
\hline Controls for backwardness ${ }^{\text {a }}$ & Yes & Yes & Yes & Yes & Yes & Yes & Yes & Yes \\
\hline Incentives, teacher, \& infrastructure ${ }^{b}$ & Yes & Yes & Yes & Yes & Yes & Yes & Yes & Yes \\
\hline District demographics ${ }^{c}$ & Yes & Yes & Yes & Yes & Yes & Yes & Yes & Yes \\
\hline State-specific trends & Yes & Yes & Yes & Yes & Yes & Yes & Yes & Yes \\
\hline Observations & $2,412,910$ & 807,709 & $2,398,334$ & 807,994 & $2,471,122$ & 825,393 & $2,450,877$ & 826,621 \\
\hline Number of schools & 834,812 & 311,403 & 833,173 & 314,233 & 839,023 & 313,675 & 836,656 & 316,481 \\
\hline
\end{tabular}

Source: Authors' analysis based on data from the District Information System for Education (2005-06 to 2008-09).

Note: a) To account for the backward district status that influenced selection into the program, the study controls for Scheduled Castes and Scheduled Tribes population from Census of India 1991, agricultural wage in 1996-97, and output per agricultural worker in 1990-93, interacted with year dummies. b) School Incentive programs include textbooks, stationery, uniforms, attendance scholarship, and other incentives; teacher characteristics include the number of male and female teachers; infrastructure includes the number of classrooms, classrooms in good condition, the existence of common toilet, women's toilet, electricity, and water facilities. c) District-level demographic characteristcs include total population, percentage of urban population, population growth rate, overall literacy rate, and women's literacy rate from the Census of India 2001. Robust standard errors clustered at district level are reported in parentheses. $* * p<0.01, * * p<0.05$, $* p<0.1$. 
Table 6. Linear Probability Regression on Child Labor (Age: 5-15, Unit: \%)

\begin{tabular}{|c|c|c|c|}
\hline Outcome variables & $\begin{array}{l}\text { Child reported working } \\
\text { (employed, self-employed, } \\
\text { or family business) } \\
\text { (1) }\end{array}$ & $\begin{array}{l}\text { Child reported doing unpaid } \\
\text { household services } \\
\text { (housework or free } \\
\text { collection of goods) } \\
\text { (2) }\end{array}$ & $\begin{array}{l}\text { Child reported active } \\
\text { (either (1) or (2)) } \\
\text { (3) }\end{array}$ \\
\hline Phase $1 \times$ Post & $\begin{array}{l}1.33 * * \\
(0.63)\end{array}$ & $\begin{array}{c}0.43 \\
(0.56)\end{array}$ & $\begin{array}{l}1.76 * * \\
(0.89)\end{array}$ \\
\hline Phase $2 \times$ Post & $\begin{array}{l}1.17^{*} \\
(0.67)\end{array}$ & $\begin{array}{c}0.36 \\
(0.51)\end{array}$ & $\begin{array}{c}1.53 * \\
(0.88)\end{array}$ \\
\hline District- and year-fixed effects & Yes & Yes & Yes \\
\hline Controls for backwardness ${ }^{\text {a }}$ & Yes & Yes & Yes \\
\hline Observations & 126,209 & 126,209 & 126,209 \\
\hline Number of districts & 438 & 438 & 438 \\
\hline
\end{tabular}

Source: Authors' analysis based on data from the National Sample Survey Office, Schedule 10, Round 61 (2004-05) and Round 66 (2008-09).

Note: a) To account for the backward district status that influenced selection into the program, the study controls for Scheduled Castes and Scheduled Tribes population from Census of India 1991, agricultural wage in 1996-97, and output per agricultural worker in 1990-93, interacted with year dummies. Robust standard errors clustered at district level are reported in parentheses. ${ }^{*} p<0.05,{ }^{*} p<0.1$.

occupation in the last month. The study examines two outcome variables: child reports working (employed, self-employed, or unpaid family labor) and child reports doing chores (housework or free collection of goods). The study restricts the sample to 206,321 nondisabled children aged between 5 and 15 from the two rounds and looks at their reported principal activities. The indicator for 'working' equals to 1 if a child's reported principal activity is working in the household enterprises (paid or unpaid), as a wage employee, or in other types of work, and 0 otherwise. The indicator for doing chores is 1 if a child's reported principal activity is attending to domestic duty or doing any other housework, and 0 otherwise. ${ }^{25}$

The empirical model is as follows:

$$
L_{i d s t}=\gamma_{0}+\gamma_{1} \text { PhaseI } * \text { Post }+\gamma_{2} \text { PhaseII } * \text { Post }+\gamma_{3} Z_{d s} * T_{t}+T_{t}+I_{d s}+\epsilon_{i d s t}
$$

where $L_{i d s t}$ is the reported labor outcome of child $i$ in district $d$ in state $s$ at time $t$. PhaseI and PhaseII are the indicators for the respective phases; $Z_{d s}$ is a vector of district-level controls for demographic characteristics, and is interacted with year indicators to control for trends in these characteristics; $T_{t}$ and $I_{d s}$ are year- and district-fixed effects, respectively, and $\epsilon_{i d s t}$ is the idiosyncratic error term. After the program, there is a 1.33 percent increase in the likelihood of child reporting working in Phase I districts relative to Phase III districts (column (1) of table 6). This is significant at the 5 percent significance level. In Phase II districts, this effect is 1.17 percent increase marginally significant at the 10 percent significance level. The study cannot reject the equality of these two coefficients. In column (2), the coefficient for doing chores is small and positive but indistinguishable from 0 . The findings indicate that child labor supply increases in response to the program.

\section{Conclusion}

The study uses the phased roll-out of MGNREGA to estimate the impact of employment-based safety net programs on schooling and labor market outcomes of children. It is found that fewer children enroll in schools in primary grades due to the introduction of the program, and their likelihood of being employed increases. This is surprising especially because the schooling aspirations for children have become stronger in the country, and large strides have been made in ensuring universal enrollment in primary schools. The

25 Other alternatives for principal activity include attending educational institution, seeking jobs, rentiers, pensioners, remittance recipients, and others. 
drop in enrollment is driven by low-quality private schools, implying that school quality affects enrollment choices when the opportunity cost of attending school shifts.

It is also found that among the enrolled, the school pass rate with more than 60 percent marks declines for grade 7 but not grade 5 students. The findings have important policy implications. All in all, unless state or market institutions increase support to offset this affects, employment-based safety programs can worsen the schooling outcomes of children.

\section{References}

Afridi, F., A. Mukhopadhyay, and S. Sahoo. 2012. "Female Labour Force Participation and Child Education in India: The Effect of the National Rural Employment Guarantee Scheme." IZA Discussion Paper No. 6593, Institute for the Study of Labor, Bonn, Germany.

Azam, M. 2012. "The Impact of Indian Job Guarantee Scheme on Labor Market Outcomes: Evidence from a Natural Experiment." IZA Discussion Paper No. 6548, Institute for the Study of Labor, Bonn, Germany.

Basu, K. 1999. "Child Labor: Cause, Consequence, and Cure, with Remarks on International Labor Standards." Journal of Economic Literature 37 (3): 1083-1119.

Basu, K., and P. H. Van. 1998. "The Economics of Child Labor." American Economic Review 88 (3): 412-27.

Berg, E., S. Bhattacharyya, R. Durgam, and M. Ramachandra. 2012. "Can Rural Public Works Affect Agricultural Wages? Evidence from India." CSAE Working Paper No. 2012-05, Centre for the Study of African Economies, Oxford University, Oxford, UK.

Berhane, G., D. Gilligan, J. Hoddinott, N. Kumar, and A. S. Taffesse. 2014. "Can Social Protection Work in Africa? The Impact of Ethiopia's Productive Safety Net Programme.” Economic Development and Cultural Change 63 (1): $1-26$.

Bernstein, B. J. 1968. "The New Deal: The Conservative Achievements of Liberal Reform." In Towards a New Past: Dissenting Essays in American History, edited by Barton J. Bernstein, 263-288. New York: Pantheon Books.

Bhatia, B., and J. Dreze. 2006. "Employment Guarantee in Jharkhand: Ground Realities." Economic and Political Weekly 41 (29): 3198-202.

Blaug, M. 1963. "The Myth of the Old Poor Law and the Making of the New." Journal of Economic History 23 (2): 151-84.

—. 1964. "The Poor Law Report Re-examined.” Journal of Economic History 24 (2): 229-45.

Cascio, E. U., and A. Narayan. 2015. "Who Needs a Fracking Education? The Educational Response to Low-Skill Biased Technological Change.” NBER Working Paper No. 21359, National Bureau of Economic Research, Cambridge, MA.

Edmonds, E. 2005. “Does Child Labor Decline with Improving Economic Status?” Journal of Human Resources 40 (1): 77-99.

Edmonds, E., and N. Pavnick. 2005. "The Effect of Trade Liberalization on Child Labor." Journal of International Economics 65 (2): 401-19.

Imbert, C., and J. Papp. 2015. "Labor Market Effects of Social Programs: Evidence from India's Employment Guarantee." American Economic Journal: Applied Economics 7 (2): 233-63.

Jacoby, H., and E. Skoufias. 1997. “Risk, Financial Markets, and Human Capital in a Developing Country.” Review of Economic Studies 64 (3): 311-35.

Jensen, R. 2000. “Development of Indicators on Child Labor.” ILO Report, International Labor Organization, Geneva, Switzerland.

Kesselman, J. R. 1978. "Work Relief Programs in the Great Depression.” In Creating Jobs: Public Employment Programs and Wage Subsidies, edited by J. L. Palmer, 153-229. Washington, DC: Brookings Institution.

Ministry of Rural Development. 2008a. Annual Report (2007-08). Government of India, see https://rural.nic.in/ sites/default/files/anualreport0708_eng.pdf.

— . 2008b. The National Rural Employment Guarantee Act 2005 (NREGA): Operational Guidelines 2008. New Delhi: Government of India, see https://nrega.nic.in/Nrega_guidelinesEng.pdf. 
Mukherjee, D., and U. B. Sinha. 2013. "Understanding NREGA: A Simple Theory and Some Facts.” In Human Capital and Development: The Indian Experience, edited by Natteri Siddharthan and Krishnan Narayanan, 103-28. New Delhi: Springer.

Planning Commission. 2003. "Identification of Districts for Wage and Self Employment Programmes." Report of the Task Force, Government of India, May.

Ravi, S., and M. Engler. 2015. "Workfare in Low Income Countries: An Effective Way to Fight Poverty? The Case of NREGS in India." World Development 67: 57-71.

Shah, M., and B. M. Steinberg. 2015. "Workfare and Human Capital Investment: Evidence from India.” NBER Working Paper No. 21543, National Bureau of Economic Research, Cambridge, MA.

Skoufias, E., and S. Parker. 2003. “The Impact of PROGRESA on Child Work and Schooling." In Child Labor and Education in Latin America, edited by P. F. Orazem, G. Sedlacek, and Z. Tzannatos, 167-85. Washington, DC: InterAmerican Development Bank and World Bank.

Skoufias, E., S. Parker, J. Behrman, and C. Pessino. 2001. "Conditional Cash Transfers and Their Impact on Child Work and Schooling: Evidence from the PROGRESA Program in Mexico.” Economica 2 (1): 45-96.

Topolova, P. 2010. "Factor Immobility and Regional Impacts of Trade Liberalization: Evidence on Poverty from India.” American Economic Journal: Applied Economics 2 (4): 1-41.

Zimmermann, L. 2012. "Labor Market Impacts of a Large-Scale Public Works Program: Evidence from the Indian Employment Guarantee Scheme.” IZA Discussion Paper No. 6858, Institute of Labor Economics, Geneva, Switzerland. 